\title{
PREVALENCE OF TMJ PAIN SYMPTOM IN ADULTS AND ITS ASSOCIATION WITH PREDISPOSING FACTORS
}

\author{
PREVALENCIA DO SINTOMA DE DOR NA ATM EM ADULTOS E SUA \\ ASSOCIAÇÃO COM FATORES PREDISPONENTES
}

\section{Michelly Cofrewirz RIBEIRO'; ${ }^{1}$ Luiza Dal Zot von MEUSEL ${ }^{2}$; Emanuela GAVIOLLI²; Alexandra Magalhães SILVEIRA ${ }^{3}$; Graziela Oro CERICATO ${ }^{4}$}

1. Dentistry at Meridional Faculty, IMED, Passo Fundo, RS, Brazil. 2. Postgraduate student in Dentistry at Meridional Faculty, IMED, Passo Fundo, RS, Brazil. 3. Master in Dentistry, Profesor at Meridional Faculty, IMED, Passo Fundo, RS, Brazil. 4. Doctor, Titular profesor in Postgraduate Program in Dentistry at Meridional Faculty, IMED, Passo Fundo, RS, Brazil. Electronic address: graziela.cericato@imed.edu.br

\begin{abstract}
To estimate the prevalence of temporomandibular joint (TMJ) pain symptom and to verify its association with predisposing or perpetuating factors. Cross-sectional study of adult patients, with 488 medical records of patients assisted at the Clinics of the School of Dentistry of IMED, in the city of Passo Fundo, RS, Brazil. The data were collected through the anamnestic record based on patient self-report. The chi-square test at 5\% significance level was used to evaluate the relationship between the outcome of TMJ pain and the variables. In addition, bivariate and multivariate Poisson analyses were performed at $5 \%$ significance level to confirm the associations, including to the multivariate analysis the variables with $\mathrm{p} \leq 0.20$ in the bivariate analysis. The prevalence of TMJ pain in this adult population was $21.52 \%(n=105)$. There was an association between TMJ pain and the variables of teeth clenching and habit of biting objects $(\mathrm{p}<0.05)$. This study concluded that the prevalence of TMJ pain symptom agrees with the mean prevalence found in the literature for studies with convenience samples, and teeth clenching and the habit of biting objects may represent perpetuating or predisposing factors for such condition.
\end{abstract}

KEYWORDS: Temporomandibular Joint. Temporomandibular Joint Dysfunction Syndrome. Temporomandibular Joint Disorders. Pain. Habits.

\section{INTRODUCTION}

Temporomandibular disorders (TMD) are an enigma and a challenge for health professionals and this may occur because they include a heterogeneous set of diseases that involves changes in the temporomandibular joints (TMJ) and mastication muscles, as well as in related structures such as the ears (AGGARWAL et al., 2006; MOTGHARE et al., 2015a).

The main symptoms of this heterogeneous condition of psychophysiologic disorders are mandibular and TMJ pain, presence of joint sounds, difficulties to open and close the mouth and to eat, and occasional pain at rest (CARDOSO; CAMPOS KRAYCHETE; CORREIA DE ARAÚJO, 2011; REGINA et al., [s.d.]). Temporomandibular disorder may often be associated with pain conditions in other parts of the body, such as the head, neck, shoulders, and back (MACFARLANE et al., 2001; WIESINGER et al., 2007).

The diagnosis is mostly based on the clinical history of the patient and the findings of the physical examination (SCRIVANI; KEITH; $\mathrm{KABAN}, 2008)$. A large retrospective study $(\mathrm{n}=$ 4528) performed by a single examiner throughout 25 years showed that the most common signs and symptoms were facial pain $(96 \%)$, auditory discomfort (82\%), headache (79\%), and mandibular discomfort or dysfunction (75\%) (COOPER; KLEINBERG, 2007).

Patients reporting orofacial pain may often present generalized pain and therefore TMD may represent the manifestation of a more comprehensive pain sensitivity disorder (AARON; BURKE; BUCHWALD, 2000). This chronic pain condition may lead to psychological, sleep, and psychosocial disorders in these patients (CARDOSO; CAMPOS KRAYCHETE; CORREIA DE ARAÚJO, 2011; OHRBACH; DWORKIN, 1998; WILSON et al., 1994).

Some population-based studies indicate that TMD affects 10 to $15 \%$ of adults and only $5 \%$ of them seek treatment (DE FIGUEIREDO et al., 2009; LIM et al., 2010), which represents a significant portion of individuals unfit to work and large medication consumers (CARDOSO; CAMPOS KRAYCHETE; CORREIA DE ARAÚJO, 2011). This condition affects more people between 20 and 40 years old, and it is twice more common in women (FILLINGIM et al., 2009; GILLBORG et al., 2017; HONGXING et al., 2016; JUSSILA et al., [s.d.]; KARIBE et al., 2015; KIM et al., 2015; MAIXNER et al., 2011; MARTINS- 
JÚNIOR et al., 2010; STUANI et al., 2008; TECCO et al., 2011), possibly due to the biological differences, including hormonal and psychosocial factors (KIM et al., 2015; WIECKIEWICZ et al., 2014).

The etiology of TMD is complex and multifactorial, and it may include biological, anatomical, environmental, social, emotional, and cognitive factors (KIM et al., 2015; WIECKIEWICZ et al., 2014). The most common causes are musculoskeletal conditions, responsible for at least $50 \%$ of the cases (REITER et al., 2012), and for the intra-articular causes, the most common one is articular disc displacement involving the condyle-disc relationship (GAUER; SEMIDEY, 2015; MURPHY et al., [s.d.]).

Factors such as parafunctional habits, joint and muscle trauma, skeletal and occlusal relationships, anxiety, and depression have not yet been explained in cross-sectional studies regarding whether they might predict the onset of TMD or even represent causal influences on the risk of TMD development (DAHLSTRÖM; CARLSSON, 2010). Hence, it is important to diagnose TMD and associate it with potential predisposing factors, in order to prevent orofacial pain.

The present study aimed to estimate the prevalence of the TMJ pain symptom and associate it with predisposing and perpetuating factors.

\section{MATERIAL AND METHODS}

\section{Study design, setting, and participants}

This cross-sectional, qualitative, and observational study was performed from March 2014 to June 2017 through a convenience sample obtained by the medical records of patients assisted at the Clinics of the School of Dentistry of IMED, in the city of Passo Fundo, Rio Grande do Sul, Brazil.

The eligibility criteria for inclusion in this study were patients over 18 and under 60 years old, without distinction of gender or race. The medical records that were not completely filled out were excluded.

\section{Sample}

From a total of 1036 medical records, 548 were excluded after applying the eligibility criteria, which resulted in a sample of 488 records. The data were collected using the information available in the anamnestic record, based on patient self-report.

\section{Variables}

Temporomandibular joint pain was considered the main outcome and it was dichotomically classified (yes/no). The other variables were considered exposure variables, such as gender (male and female), age (19-30, 31-45, 4660 ), marital status (single, married and/or with a partner, widow(er), divorced) level of education (incomplete elementary school, complete elementary school/incomplete high school, complete high school/incomplete higher education, complete higher education), depressive disorder (yes/no), coffee consumption (yes/no), previous facial trauma (yes/no), habit of biting nails (yes/no), biting objects (yes/no), and teeth clenching (yes/no), regardless of whether it was a day or night habit.

\section{Data collection}

The data were initially collected with the creation of an Excel spreadsheet to fill out data such as gender, age, marital status, level of education, depressive disorder, coffee consumption, TMJ pain, previous facial trauma, habit of biting nails, biting objects, and teeth clenching.

\section{Statistical analysis}

All data were analyzed by the Stata ${ }^{\mathrm{TM}} 12$ software (StataCorp $^{\mathrm{TM}}$ LP, Texas, USA). First, a descriptive analysis was performed for the main characteristics of the sample by means of relative and absolute frequencies, and the prevalence of the main outcome (TMJ pain) was calculated. Pearson's chi-square test was applied to verify the association between the presence of TMJ pain and the independent variables. Bivariate and multivariate Poisson analyses were performed at 5\% significance level to confirm the associations, including to the multivariate analysis the variables with $p \leq 0.20$ in the bivariate analysis.

\section{Ethical considerations}

The present study was approved by the Research Ethics Committee of Faculdade Meridional/IMED, under report \#638.976/2014.

\section{RESULTS}

In this study, most of the sample consisted of women $(86.68 \%)$ and the prevalent age group was $46-60$ years $(42.62 \%)$. As for the level of education, most of the sample had completed high school/incomplete higher education $(41.60 \%)$. The prevalence of patients with TMJ pain symptom was $21.52 \%(\mathrm{n}=105)$.

Table 1 shows the association between the main outcome (TMJ pain) and the independent variables. 
Table 1. Distribution of independent variables associated with TMJ pain $(n=488)$.

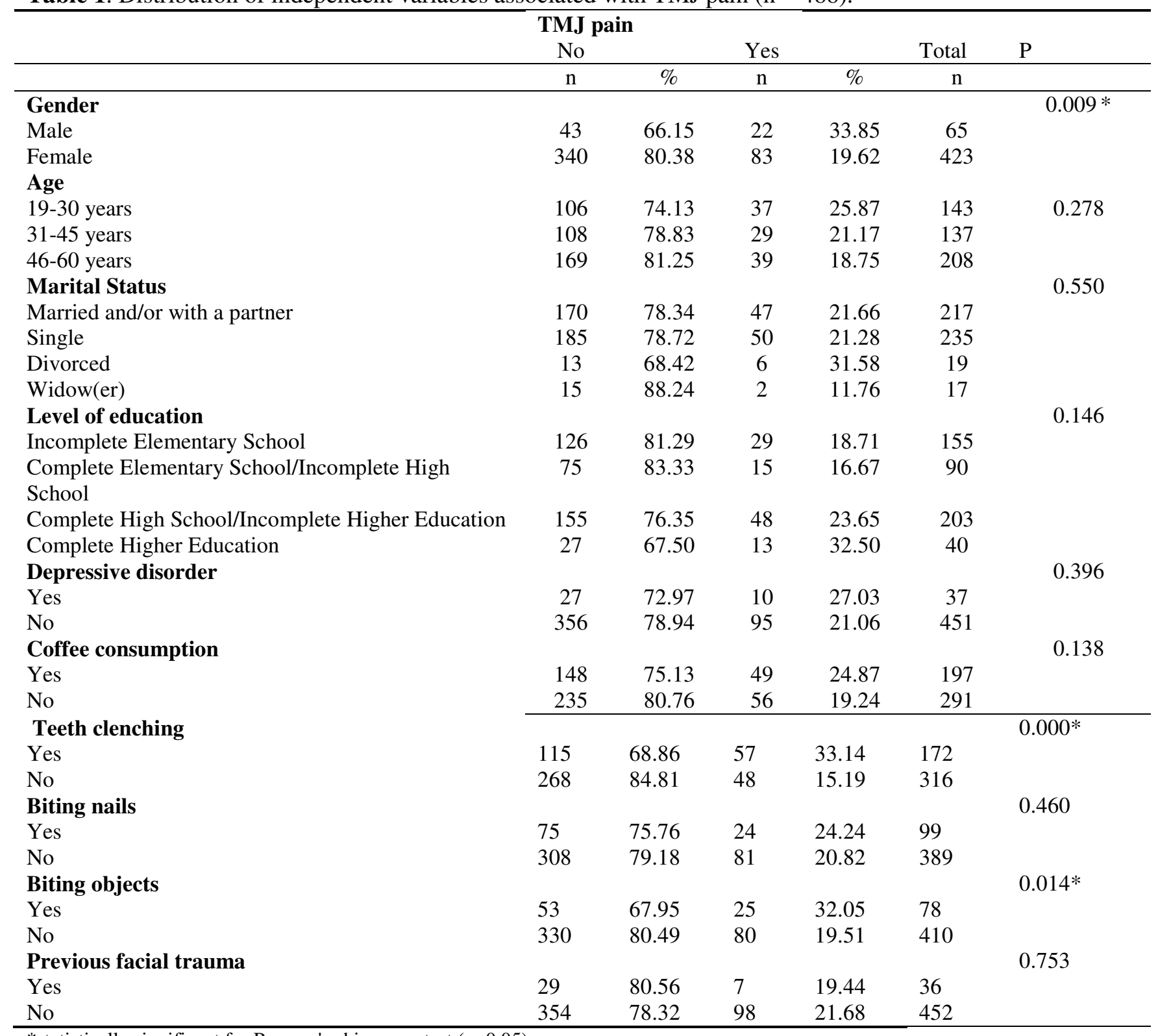

*statistically significant for Pearson's chi-square test $(\mathrm{p}<0.05)$

The prevalence reasons obtained in the multivariate analysis with the variables associated with TMJ pain are presented in Table 2.

Table 2. Association between TMJ pain and associated factors, by the bivariate and multivariate regression analysis.

\begin{tabular}{lllll}
\hline & TMJ pain & & & \\
\hline & Bivariate Analysis & & Multivariate Analysis & \\
& & $\mathrm{p}$ & & $\mathrm{p}$ \\
Gender & $1.72(1.07 ; 2.75)$ & $0.02^{*}$ & $1.44(0.84 ; 2.45)$ & 0.17 \\
Level of education & $1.18(0.97 ; 1.43)$ & $0.08^{*}$ & $1.10(0.89 ; 1.35)$ & 0.35 \\
Coffee consumption & $0.77(0.52 ; 1.13)$ & 0.19 & $0.86(0.58 ; 1.27)$ & 0.46 \\
Biting objects & $1.64(1.04 ; 2.57)$ & $0.03^{*}$ & $1.62(1.03 ; 2.5)$ & $0.03^{* *}$ \\
Teeth clenching & $2.18(1.48 ; 3.20)$ & $0.00^{*}$ & $2.11(1.43 ; 3.11)$ & $0.00^{* *}$ \\
\hline
\end{tabular}

*statistically significant for the bivariate Poisson analysis, $5 \%$ significance level; **statistically significant for the multivariate Poisson analysis, $5 \%$ significance level. 


\section{DISCUSSION}

Among the types of orofacial pain, the second type of disorder most commonly found is the temporomandibular disorder (TMD), with prevalence estimated between 3 and $15 \%$ of the population (BENDER, 2014). However, studies show that such prevalence may vary from $4.9 \%$ (ADÈRN et al., 2014) to 60\% (CAMPOS et al., 2014) according to the age of the individuals studied (FARSI, 2003). In a cohort study from 1966 performed in Northern Finland, 1962 individuals aged 46 years old in average were interviewed from 2012 to 2013 and $18.5 \%$ self-reported the presence of TMJ pain (JUSSILA et al., [s.d.]). On the other hand, a study performed in Sweden with 6300 participants showed by means of self-report that $11 \%$ of the adult population presented TMJ pain (GILLBORG et al., 2017). In the present study, $21.52 \%$ of patients reported having temporomandibular joint pain. These data should be interpreted considering that the sample included patients assisted in the dental clinic of IMED, meaning these were patients seeking dental care, and that data were extracted from the clinical files by means of patient self-report, which may have overestimated this symptom.

However, most of the epidemiological studies on TMD have been limited to cross-sectional or case-control designs, mostly with convenience samples. These studies report higher prevalence in women than in men, with a ratio ranging from $2: 1$ for the general population and 8:1 in the clinical environment (BUSH et al., 1993).

In the present study, the patients that selfreported TMJ pain were mostly women $(86.68 \%)$. However, when performing the statistical analysis of multivariate correlation, the factor of gender cannot be considered a risk factor for TMD for this specific sample in our study. The evidence shown over the last years indicates substantial differences of gender in the clinical and experimental responses to pain. Women present higher prevalence of painful conditions than men, including orofacial pain and other TMD symptoms (FILLINGIM et al., 2009).

In a 3-year prospective study with 266 participating women aged 18 through 34 years, initially free of pain, 16 patients $(6 \%)$ developed TMD. Such development was followed by increased headache, muscle pain, and other types of pain that were not observed in participants who had not developed TMD. The participants who developed the condition also reported experiencing more back, chest, and menstrual pain at the beginning of the study than the participants who had not developed TMD (LIM et al., 2010).

Several studies corroborate these findings with the reason that women in reproductive age (20 to 40 years old) constitute the great majority (around $80 \%$ ) of individuals suffering from TMD, which raises interest on genetic and hormonal issues that may explain this fact. It was observed that polymorphisms in genes that code the enzymes involved in the metabolism of estrogen are candidates for the list of TMD support (CARDOSO; KRAYCHETE, 2010; FERREIRA; SILVA; FELÍCIO, 2016).

Some studies also associate this prediction for the female gender as an interaction of biological (differences in muscle structure and connective tissue), hormonal, psychological, and social factors (PRESS; FACIAL; DIGITAL, 2008; WARREN; FRIED, 2001).

The studies show that several factors have been investigated for a potential relation to TMD, including bruxism (MOLINA et al., 1997), teeth grinding or clenching, biting the tongue, cheeks, lips, or nails (DE LEEUW et al., 1994; MARBACH; LENNON; DOHRENWEND, 1988; TSOLKA et al., 1995), history of moderate or severe trauma, and orthodontic treatment or third molar extraction (PULLINGER; MONTEIRO, 1988), as well as other factors such as headaches (DE LEEUW et al., 1994; MOLINA et al., 1997), pain in other parts of the body (DE LEEUW et al., 1994; MORROW et al., 1996), depression, stress, and anxiety (DAHLSTRÖM; CARLSSON, 2010; DE LEEUW et al., 1994; MARBACH; LENNON; DOHRENWEND, 1988).

The present study showed, after the multivariate analysis, an association between some factors such as teeth clenching (IRR: 2.11; CI 95\% 1.43-3.11) and the habit of biting objects (IRR: 1.62; CI 95\% 1.03-2.5), which are considered microtraumas, with TMJ pain symptoms reported by the patients. Similar results were observed by Motghare et al., in their study with adolescents ages 10 through 19 years, which verified the association of the habit of biting lips, objects, and nails, and teeth clenching with signs and symptoms of TMD, showing higher prevalence of signs and symptoms observed in women (MOTGHARE et al., 2015b).

In another study performed with adolescents aged 16 through 19 years to verify the prevalence of signs and symptoms of TMD and its relation to parafunctional habits, the habit of biting objects was significantly associated with the presence of TMD symptoms (OLIVEIRA et al., 2016). 
Other studies show a relation of parafunctional habits as contributing factors that either predispose TMD or are considered risk factors (KARIBE et al., 2015; KOBS et al., 2005; OLIVEIRA et al., 2016; WINOCUR et al., 2006).

According to Fernandes et al., in their study with adolescents to investigate predisposing factors of TMD pain, there was an association with parafunctional habits. They also claimed that parafunctional habits promote the maintenance and/or progression of TMD pain, leading to muscle overload and consequently worsening the disorder (FERNANDES et al., 2015).

According to Sproesser, the habit of teeth clenching does not necessarily induce the painful symptom of the disorder (SPROESSER, 2002). However, the literature reports that the parafunctional habits are risk factors of TMD (RODA et al., 2007).

Studies affirm that stress has a large influence on TMD, acting as an etiological factor for the production of parafunctional habits, and it is an aggravating factor for the pathological condition, affecting the quality of life and consequently the social life of the individual (RESENDE et al., [s.d.]; SUVINEN et al., 2004).

The association between pain and teeth clenching may be attributed to either damaged muscle fibers or a reduction of blood supply, considering the perfusion of the masseter is significantly hindered in individuals with voluntary isometric contractions (MICHELOTTI et al., 2010). Moreover, chronic teeth clenching increases the friction between the TMJ components by decreasing the proper lubrication from the synovial fluid, and a hypothesis is created to explain the beginning of the process of articular disc displacement, which causes pain (CARDOSO; KRAYCHETE, 2010).

This study presents the association between some predisposing factors and TMD pain. Because they are important factors for the development of TMD, these variables deserve the attention of health professionals. However, it is worth noting the existent number of studies performed on TMD and the great difficulty to compare such studies due to the lack of standardization of diagnostic criteria.

This study had some limitations. It was a cross-sectional study with a convenience sample of patients assisted in a dental school, and therefore it may not represent a population. However, the results show associations with some factors such as parafunctional habits and biting objects, which agrees with the literature consulted. Thus, more attention should be given to such habits when patients report them, in order to prevent diseases and/or early treatment to hinder the evolution of the condition to more severe cases.

Moreover, the study will continue in a second phase with the return visit of patients who reported TMJ pain, for a concrete diagnosis of TMD and the proper treatment of these patients.

\section{CONCLUSION}

The prevalence of TMJ pain symptom agrees with the mean prevalence found in the literature for his type of study, and that teeth clenching and the habit of biting objects may be perpetuating or predisposing factors for such condition.

\section{ACKNOWLEDGEMENTS}

This study was financed in part by the Coordenação de Aperfeiçoamento de Pessoal de Nível Superior - Brasil (CAPES) - Finance Code 001 .

RESUMO: Estimar a prevalência do sintoma dor na articulação temporomandibular (ATM) e verificar sua associação com fatores predisponentes ou perpetuantes. Estudo transversal de pacientes adultos, com 488 prontuários de pacientes atendidos na Clínica de graduação da Escola de Odontologia da IMED do município de Passo Fundo. Os dados foram coletados através da ficha anamnésica baseando-se no auto relato, do paciente. O teste do qui-quadrado, com nível de significância de 5\%, foi utilizado para avaliar a relação entre o desfecho dor na ATM e as variáveis. E para confirmar as associações, foram realizadas análises de Poisson, bivariada e multivariada, com nível de significância de 5\%, sendo incluídas na análise multivariada as variáveis com $\mathrm{p} \leq 0,20$ na análise bivariada. A prevalência de dor na ATM nessa população adulta foi de 21,52\% (n=105). Encontrou-se associação entre dor na ATM e as variáveis apertamento dental e hábito de morder objetos $(\mathrm{p}<0.05)$. Neste estudo pode - se concluir que a prevalência do sintoma dor na ATM está de acordo com a média de prevalência encontrada na literatura para estudos com amostra de conveniência e os fatores apertamento dental e hábito de morder objetos podem ser perpetuantes ou predisponentes para tal condição.

PALAVRAS-CHAVE: Articulação Temporomandibular. Síndrome da disfunção da Articulação Temporomandibular. Transtornos da Articulação Temporomandibular. Dor. Hábitos. 


\section{REFERENCES}

AARON, L. A.; BURKE, M. M.; BUCHWALD, D. Overlapping conditions among patients with chronic fatigue syndrome, fibromyalgia, and temporomandibular disorder. Archives of internal medicine, v. 160, n. 2, p. 221-7, 24 Jan. 2000. https://doi.org/10.1001/archinte.160.2.221

ADÈRN, B. et al. Prevalence of temporomandibular dysfunction and pain in adult general practice patients. Acta Odontologica Scandinavica, v. 72, n. 8, p. 585-590, 28 Nov. 2014. https://doi.org/10.3109/00016357.2013.878390

AGGARWAL, V. R. et al. The epidemiology of chronic syndromes that are frequently unexplained: do they have common associated factors? International journal of epidemiology, v. 35, n. 2, p. 468-76, Apr. 2006. https://doi.org/10.1093/ije/dyi265

BENDER, S. D. Orofacial pain and headache: a review and look at the commonalities. Current pain and headache reports, v. 18, n. 3, p. 400, 2014. https://doi.org/10.1007/s11916-013-0400-5

BUSH, F. M. et al. Analysis of gender effects on pain perception and symptom presentation in temporomandibular pain. Pain, v. 53, n. 1, p. 73-80, Apr. 1993. https://doi.org/10.1016/0304-3959(93)90058$\mathrm{W}$

CAMPOS, J. A. D. B. et al. Epidemiology of severity of temporomandibular disorders in Brazilian women. Journal of oral \& facial pain and headache, v. 28, n. 2, p. 147-52, 2014. https://doi.org/10.11607/ofph.1194

CARDOSO, L. M.; CAMPOS KRAYCHETE, D.; CORREIA DE ARAÚJO, R. P. A relevância do apertamento dentário nas desordens temporomandibulares The relevance of teeth clenching on temporomandibular disorders ARTIGO DE REVISÃO. med. biol, n. 103, p. 277-283, 2011.

CARDOSO, L. M.; KRAYCHETE, D. C. A relevância do apertamento dentário nas desordens temporomandibulares The relevance of teeth clenching on temporomandibular disorders. p. 277-283, 2010.

COOPER, B. C.; KLEINBERG, I. Examination of a Large Patient Population for the Presence of Symptoms and Signs of Temporomandibular Disorders. CRANIO®, v. 25, n. 2, p. 114-126, Apr. 2007. https://doi.org/10.1179/crn.2007.018

DAHLSTRÖM, L.; CARLSSON, G. E. Temporomandibular disorders and oral health-related quality of life. A systematic review. Acta Odontologica Scandinavica, v. 68, n. 2, p. 80-85, 8 Mar. 2010. https://doi.org/10.3109/00016350903431118

DE FIGUEIREDO, V. M. G. et al. Prevalência de sinais, sintomas e fatores associados em portadores de disfunção temporomandibular. Acta Scientiarum - Health Sciences, 2009.

DE LEEUW, J. R. et al. Multidimensional evaluation of craniomandibular dysfunction. I: Symptoms and correlates. Journal of oral rehabilitation, v. 21, n. 5, p. 501-14, Sep. 1994. https://doi.org/10.1111/j.13652842.1994.tb01166.x https://doi.org/10.1111/j.1365-2842.1994.tb01165.x

FARSI, N. M. A. Symptoms and signs of temporomandibular disorders and oral parafunctions among Saudi children. Journal of oral rehabilitation, v. 30, n. 12, p. 1200-8, Dec. 2003. https://doi.org/10.1111/j.13652842.2003.01187.x

FERNANDES, G. et al. Factors associated with temporomandibular disorders pain in adolescents. Journal of Oral Rehabilitation, v. 42, n. 2, p. 113-119, Feb. 2015. https://doi.org/10.1111/joor.12238 
FERREIRA, C. L. P.; SILVA, M. A. M. R. DA; FELÍCIO, C. M. DE. Sinais e sintomas de desordem temporomandibular em mulheres e homens. CoDAS, v. 28, n. 1, p. 17-21, 2016. https://doi.org/10.1590/2317$1782 / 20162014218$

FILLINGIM, R. B. et al. Sex, Gender, and Pain: A Review of Recent Clinical and Experimental Findings. Journal of Pain, v. 10, n. 5, p. 447-485, 2009. https://doi.org/10.1016/j.jpain.2008.12.001

GAUER, R. L.; SEMIDEY, M. J. Diagnosis and treatment of temporomandibular disorders. American family physician, v. 91, n. 6, p. 378-86, 15 Mar. 2015.

GILLBORG, S. et al. Temporomandibular Disorder Pain and Related Factors in an Adult Population: A CrossSectional Study in Southern Sweden. Journal of Oral \& Facial Pain and Headache, v. 31, n. 1, p. 37-45, 2017. https://doi.org/10.11607/ofph.1517

HONGXING, L. et al. Prevalence of temporomandibular disorder pain in Chinese adolescents compared to an age-matched Swedish population. Journal of oral rehabilitation, v. 43, n. 4, p. 241-8, Apr. 2016. https://doi.org/10.1111/joor.12366

JUSSILA, P. et al. Prevalence of Temporomandibular Disorders in the Northern Finland Birth Cohort 1966. Journal of oral \& facial pain and headache, v. 31, n. 2, p. 159-164, [s.d.].

KARIBE, H. et al. Prevalence and association of self-reported anxiety, pain, and oral parafunctional habits with temporomandibular disorders in Japanese children and adolescents : a cross-sectional survey. p. 1-7, 2015.

KIM, T.-Y. et al. Gender Difference in Associations between Chronic Temporomandibular Disorders and General Quality of Life in Koreans: A Cross-Sectional Study. PloS one, v. 10, n. 12, p. e0145002, 16 Dec. 2015. https://doi.org/10.1371/journal.pone.0145002

KOBS, G. et al. Oral parafunctions and positive clinical examination findings. Stomatologija, v. 7, n. 3, p. 81$3,2005$.

LIM, P. F. et al. Development of temporomandibular disorders is associated with greater bodily pain experience. The Clinical journal of pain, v. 26, n. 2, p. 116-20, Feb. 2010.

https://doi.org/10.1097/AJP.0000000000000385

https://doi.org/10.1097/AJP.0b013e3181c507ef

MACFARLANE, T. V et al. Factors associated with the temporomandibular disorder, pain dysfunction syndrome (PDS): Manchester case-control study. Oral diseases, v. 7, n. 6, p. 321-30, Nov. 2001. https://doi.org/10.1034/j.1601-0825.2001.00758.x

MAIXNER, W. et al. Orofacial Pain Prospective Evaluation and Risk Assessment Study - The OPPERA Study. The Journal of Pain, v. 12, n. 11, p. T4-T11.e2, Nov. 2011.

MARBACH, J. J.; LENNON, M. C.; DOHRENWEND, B. P. Candidate risk factors for temporomandibular pain and dysfunction syndrome: psychosocial, health behavior, physical illness and injury. Pain, v. 34, n. 2, p. 139-51, Aug. 1988. https://doi.org/10.1016/0304-3959(88)90159-5

MARTINS-JÚNIOR, R. L. et al. Temporomandibular disorders: a report of 124 patients. The journal of contemporary dental practice, v. 11, n. 5, p. 071-8, 14 Oct. 2010.

MICHELOTTI, A. et al. Oral Rehabilitation Oral parafunctions as risk factors for diagnostic TMD subgroups. 2010. 
MOLINA, O. F. et al. Prevalence of modalities of headaches and bruxism among patients with craniomandibular disorder. Cranio : the journal of craniomandibular practice, v. 15, n. 4, p. 314-25, Oct. 1997. https://doi.org/10.1080/08869634.1997.11746026

MORROW, D. et al. Relationship of other joint problems and anterior disc position in symptomatic TMD patients and in asymptomatic volunteers. Journal of orofacial pain, v. 10, n. 1, p. 15-20, 1996.

MOTGHARE, V. et al. Association Between Harmful Oral Habits and Sign and Symptoms of Temporomandibular Joint Disorders Among Adolescents. p. 45-48, 2015a.

MOTGHARE, V. et al. Association Between Harmful Oral Habits and Sign and Symptoms of Temporomandibular Joint Disorders Among Adolescents. JOURNAL OF CLINICAL AND DIAGNOSTIC RESEARCH, v. 9, n. 8, p. ZC45-8, Aug. 2015b.

MURPHY, M. K. et al. Temporomandibular disorders: a review of etiology, clinical management, and tissue engineering strategies. The International journal of oral \& maxillofacial implants, v. 28, n. 6, p. e393-414, [s.d.]. https://doi.org/10.11607/jomi.te20

OHRBACH, R.; DWORKIN, S. F. Five-year outcomes in TMD: relationship of changes in pain to changes in physical and psychological variables. Pain, v. 74, n. 2-3, p. 315-26, Feb. 1998. https://doi.org/10.1016/S03043959(97)00194-2

OLIVEIRA, C. B. DE et al. Temporomandibular disorders and oral habits in high-school adolescents: a public health issue? RGO - Revista Gaúcha de Odontologia, v. 64, n. 1, p. 8-16, 2016.

PRESS, R. D.; FACIAL, O.; DIGITAL, B. Frequência de relatos de parafunções nos subgrupos diagnósticos de DTM de acordo com os critérios diagnósticos para pesquisa em disfunções temporomandibulares ( RDC / TMD ). p. 61-69, 2008.

PULLINGER, A. G.; MONTEIRO, A. A. Functional impairment in TMJ patient and nonpatient groups according to a disability index and symptom profile. Cranio : the journal of craniomandibular practice, v. 6 , n. 2, p. 156-64, Apr. 1988. https://doi.org/10.1080/08869634.1988.11678233

REGINA, S. et al. CARACTERIZAÇÃO DOS PACIENTES DE UM AMBULATÓRIO DE DISFUNÇÃO TEMPOROMANDIBULAR E DOR OROFACIAL 1. [s.d.].

REITER, S. et al. Masticatory muscle disorders diagnostic criteria: the American Academy of Orofacial Pain versus the research diagnostic criteria/temporomandibular disorders (RDC/TMD). Journal of oral rehabilitation, v. 39, n. 12, p. 941-7, Dec. 2012. https://doi.org/10.1111/j.1365-2842.2012.02337.x

RESENDE, C. M. B. M. DE et al. Quality of life and general health in patients with temporomandibular disorders. Brazilian oral research, v. 27, n. 2, p. 116-21, [s.d.]. https://doi.org/10.1590/S180683242013005000006

RODA, R. P. et al. Review of temporomandibular joint pathology . Part I : Classification, epidemiology and risk factors. p. 292-298, 2007.

SCRIVANI, S. J.; KEITH, D. A.; KABAN, L. B. Temporomandibular Disorders. New England Journal of Medicine, v. 359, n. 25, p. 2693-2705, 18 Dec. 2008. https://doi.org/10.1056/NEJMra0802472

SPROESSER, J. G. Características das Relações Interoclusais em Indivíduos com Mastigação Realizada Preferencialmente Sobre um dos Lados e Sintomas de Disfunção Temporomandibular. Jornal Brasileiro de Oclisão, ATM e Dor Orofacial, v. 2, n. 5, 2002.

STUANI, A. S. et al. Unilateral correction of space loss in the mixed dentition. Pediatric dentistry, v. 30, n. 4, p. 334-341, 2008. 
SUVINEN, T. I. et al. An 8-year follow-up study of temporomandibular disorder and psychosomatic symptoms from adolescence to young adulthood. Journal of orofacial pain, v. 18, n. 2, p. 126-30, 2004.

TECCO, S. et al. Signs and Symptoms of Temporomandibular Joint Disorders in Caucasian Children and Adolescents. CRANIO®, v. 29, n. 1, p. 71-79, Jan. 2011. https://doi.org/10.1179/crn.2011.010

TSOLKA, P. et al. Occlusal variables, bruxism and temporomandibular disorders: a clinical and kinesiographic assessment. Journal of oral rehabilitation, v. 22, n. 12, p. 849-56, Dec. 1995. https://doi.org/10.1111/j.13652842.1995.tb00233.x

WARREN, M. P.; FRIED, J. L. Temporomandibular disorders and hormones in women. Cells Tissues Organs, v. 169, n. 3, p. 187-192, 2001. https://doi.org/10.1159/000047881

WIECKIEWICZ, M. et al. Prevalence and correlation between TMD based on RDC/TMD diagnoses, oral parafunctions and psychoemotional stress in Polish university students. BioMed research international, v. 2014, p. 472346, 2014. https://doi.org/10.1155/2014/472346

WIESINGER, B. et al. Back pain in relation to musculoskeletal disorders in the jaw-face: a matched casecontrol study. Pain, v. 131, n. 3, p. 311-9, Oct. 2007. https://doi.org/10.1016/j.pain.2007.03.018

WILSON, L. et al. Somatization and pain dispersion in chronic temporomandibular disorder pain. Pain, v. 57, n. 1, p. 55-61, Apr. 1994. https://doi.org/10.1016/0304-3959(94)90107-4

WINOCUR, E. et al. Oral habits and their association with signs and symptoms of temporomandibular disorders in adolescents: a gender comparison. Oral surgery, oral medicine, oral pathology, oral radiology, and endodontics, v. 102, n. 4, p. 482-7, Oct. 2006. https://doi.org/10.1016/j.tripleo.2005.11.007 